\title{
Impact of the Great East Japan Earthquake on Reproductive Biology of the Freshwater Teleost Bluegill Lepomis macrochirus
}

\author{
Eri Iwata", Hideaki Sasaki and Kenji Sato
}

College of Science and Engineering, Iwaki Meisei University, Iwaki, Japan

\begin{abstract}
Soon after the Great East Japan Earthquake and the subsequent accident at the Fukushima Daiichi nuclear power plant, we studied the reproductive biology of freshwater teleost bluegill (Lepomis macrochirus) in a pond in the city of Iwaki, Fukushima Prefecture, about $50 \mathrm{~km}$ south of the nuclear power plant. The breeding period of the bluegill was abbreviated and the frequency of spawning decreased. The radiation air dose rate and level of radioactivity in the fish were less than would be expected to trigger behavioural alterations or to suppress reproduction. The occurrence of aftershocks and two episodes of torrential rain is the likely reason for changes in the reproductive behaviour of bluegill in the pond. These results suggest that our observations can be explained by a combination of natural disasters, rather than the effects of nuclear radiation.
\end{abstract}

Keywords: Radiation, spawning, teleost, vibration, water temperature.

\section{INTRODUCTION}

The bluegill, Lepomis macrochirus (Rafinesque, 1819), is the most common species of sunfish. It is native to the North American continent and is the one of the commonest introduced species in Japan. The bluegill was introduced into Japan as a gift by the then mayor of Chicago to the then crown prince of Japan in 1960. The prince donated the fish to fishery research agencies in Japan, from which they escaped, becoming an invasive species. The fish expanded its distribution rapidly, and can now be found in almost all freshwater lakes, ponds and rivers, which is regarded as a pest that seriously affects Japanese freshwater ecosystems [1]. The bluegill has been successful partly because the males are highly aggressive. The males are territorial, build nests in colonies, aggressively court females, readily spawn, and guard the eggs and larvae in the nests [2].

Starting in 2008, we have monitored the reproductive behaviour of male bluegill in a pond in the city of Iwaki, in Fukushima Prefecture, Japan. In this pond, the breeding period runs from June to August; over the years we have observed between three and six episodes of group spawning during this period.

On 11 March 2011, the Tohoku district of Japan, where our study pond is located, experienced an earthquake of magnitude 9.0. This triggered an accident in the Fukushima Daiichi nuclear power plant (NPP), and radiation was released. The bluegill breeding pattern in 2011, after the disaster, differed from that observed previously. In an effort to determine why this was so, we measured several environ-

*Address correspondence to this author at the College of Science and Technology, Iwaki Meisei University, Iwaki, Japan; Tel: +81-246-29-7157; Fax: +81-246-29-0577; E-mail; asealion@iwakimu.ac.jp mental parameters, including the radiation air dose rate and the extent of radioactive contamination of fish.

\section{MATERIALS AND METHODOLOGY}

The reproductive behaviour of male bluegill was observed from 2008 to 2012 in a study pond $\left(37^{\circ} 02^{\prime} \mathrm{N}, 140^{\circ} 92^{\prime}\right.$ E) located near our University, which is situated about $50 \mathrm{~km}$ south of the Fukushima Daiichi NPP (in Iwaki, Fukushima Prefecture, Japan (Fig. 1). We conducted observations from 07:00 to 09:00 every day during the breeding period, except when the days of adverse weather. Each breeding period was considered to start when the males were observed to be guarding nests, and to end when such behaviour ceased. We enumerated the numbers of territorial males guarding nests and the frequency at which such fish chased other fish away. We recorded the days on which group spawning occurred. The water temperature was monitored daily.

In January 2012, we captured some fish with rods and measured their length and body and gonad weights. We also measured the concentrations of radioactive $\mathrm{Cs}_{134}$ and $\mathrm{Cs}_{137}$ in fillets with an $\mathrm{NaI}$ scintillation counter (CAN-OSP-NAI; Hitachi-Aloka Medical Ltd., Tokyo, Japan). Levels of radioactivity in pond water, pond mud, and pond algae were also measured. Radiation air dose rate in the vicinity of the pond was monitored between two and five times monthly with the aid of a scintillation survey meter (TCS-171B; HitachiAloka Medical Ltd.). The occurrence of aftershocks was recorded by monitoring the website of our local meteorological observatory (http://www.jma-net.go.jp/fukushi$\mathrm{ma} /$ jishin/jishin_katsudo.html).

All experimental protocols conformed with the policies of Iwaki Meisei University that govern the use of live vertebrate animals in research, as well as the Guidelines for Re- 


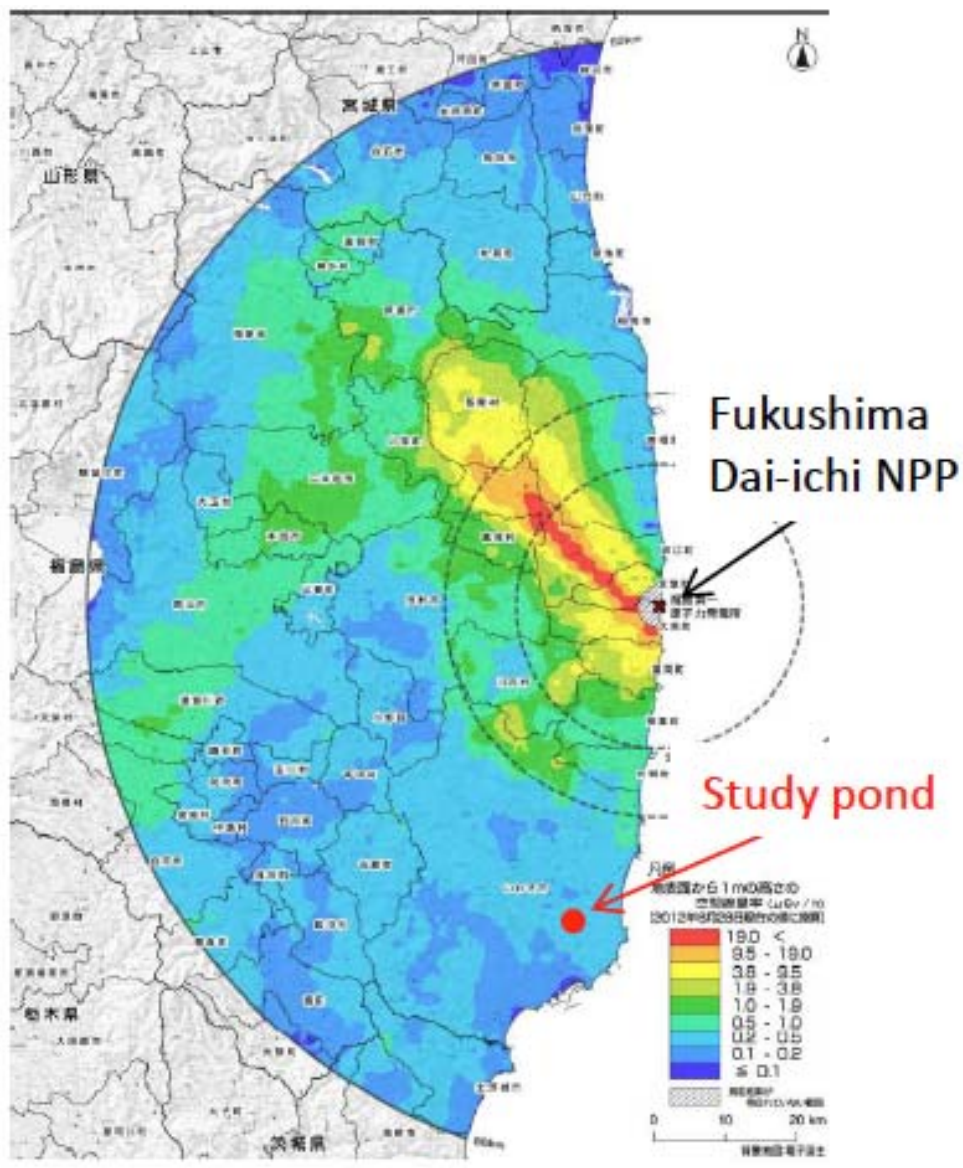

Fig. (1). Radiation air dose rates in July 2011 within a $100 \mathrm{~km}$ radius of the Fukushima Daiichi nuclear power plant (http://ramap.jmc.or.jp/map/map.html), and the location of our study pond.

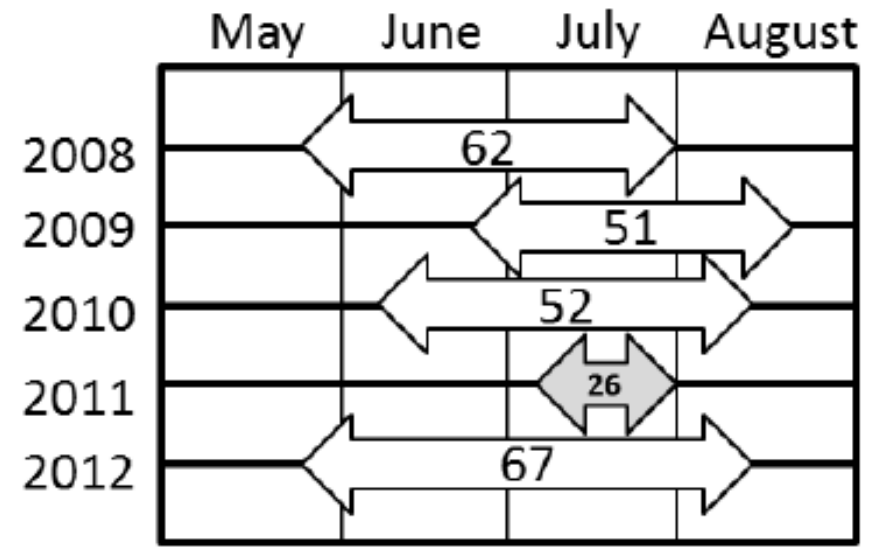

Fig. (2). Durations, in days, of the breeding periods of bluegill in our study pond in Iwaki, Japan, from 2008 to 2012 . The abbreviated breeding period of 2011 is shown in grey.

search on Animal Behaviour promulgated by the Japan Ethological Society.

\section{RESULTS}

In 2011, in the morning of 20 June, we found newly build, but abandoned nine nests in our study pond, which were rapidly covered by mud and disappeared in two days. Finally, our bluegill began to breed on 6 July, more than 1 month later than in previous years. Breeding ended on
1 August, at a time similar to that noted in previous years. The duration of the breeding season was thus only 26 days, dramatically less than in previous years (Fig. 2). In 2011, because the breeding period was truncated, group spawning was observed only twice. However, the territorial males exhibited intensely aggressive behaviour, chasing intruders away much more frequently than was the case in previous years. These behavioural changes did not persist into 2012, although the aggressive behaviour still occurred at a higher rate than before the earthquake (Table 1). 
Table 1. Average water temperature of the study pond, maximum number of nests, frequency of mean territorial defense behaviour of male, and frequency of group spawning of bluegill in the study pond from 2008 to 2012 breeding period. The data of mean territorial defense behaviour of 2010 was missing by the earthquake.

\begin{tabular}{|c|c|c|c|c|}
\hline Year & WT (Range) ${ }^{\circ} \mathbf{C}$ & Nests & Defence/Male & $12.45 \pm 1.83$ \\
\hline \hline 2008 & $22.3 \pm 0.4(20-25)$ & 9 & $10.11 \pm 4.04$ & 3 \\
\hline 2009 & $25.4 \pm 0.4(22-28)$ & 12 & - & 6 \\
\hline 2010 & $26.7 \pm 0.3(22-30)$ & 31 & $60.23 \pm 5.02$ & 2 \\
\hline 2011 & $25.8 \pm 0.8(18-30)$ & 9 & $22.89 \pm 4.04$ & 6 \\
\hline
\end{tabular}

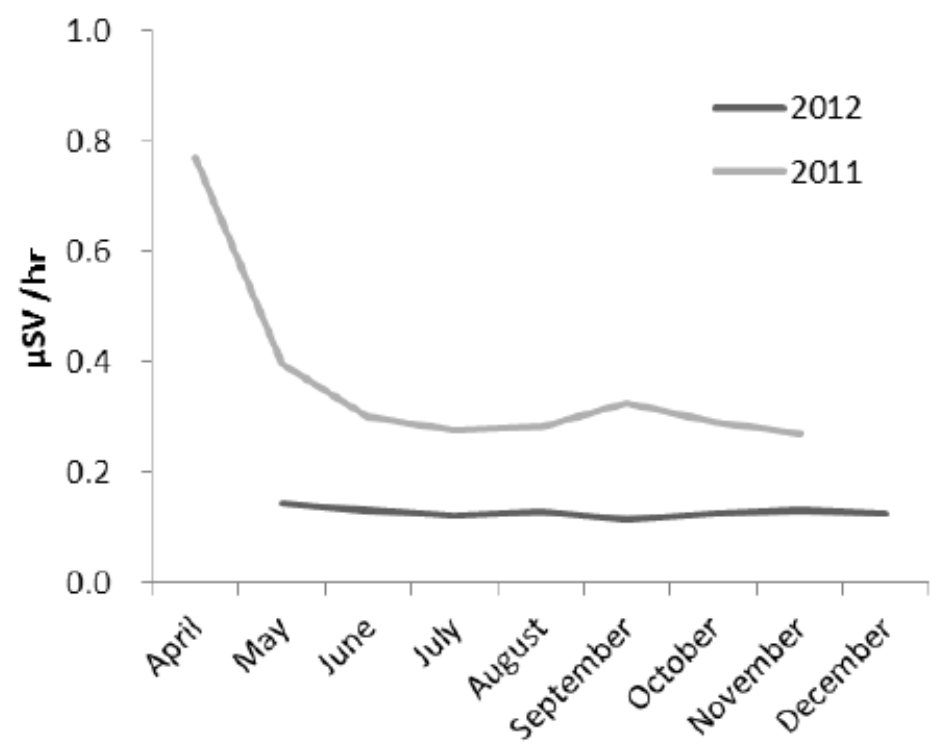

Fig. (3). Monthly averages of radiation air dose rates in the vicinity of our study pond from April 2011 to December 2012 . No data were available from December 2011 to April 2012. The durations of breeding periods are shown by black (2011) and white (2010) bars terminated by arrowheads.

The radiation air dose rate in the vicinity of the pond peaked at $0.85 \mu \mathrm{SV} / \mathrm{h}$ early in April 20, 2011 and fell to 0.22 to $0.33 \mu \mathrm{SV} / \mathrm{h}$ during the 2011 breeding period (Fig. 3). The rate was 0.12 to $0.10 \mu \mathrm{SV} / \mathrm{h}$ during the 2012 breeding period.

Small amounts of radioactivity were detected in fish captured in January 2012; the levels were $136 \mathrm{~Bq} / \mathrm{kg}-\mathrm{FW}$ (fresh weight) in males and $215 \mathrm{~Bq} / \mathrm{kg}-\mathrm{FW}$ in females. The level in pond algae was $678 \mathrm{~Bq} / \mathrm{kg}-\mathrm{FW}$, but the water concentration was below measurable limits. Notably, however, the level in pond mud was high, at 28,000 Bq/kg-DW (dry weight).

The Great East Japan Earthquake on 11 March 2011 was followed by many aftershocks that extended throughout the 2011 breeding period. Aftershocks of seismic intensity of 1.0 or more were recorded on 1292 occasions in March, 938 in April, 396 in May, 245 in June, 209 in July, and 216 in August (Fig. 4). Importantly, an aftershock with a seismic intensity of 6.0 occurred on 11 April 2011. This aftershock originated in a fault line located about $30 \mathrm{~km}$ WSW of Iwaki and caused great damage. In some locations, the effects were more serious than were those of the earlier, principal, earthquake.

The trend in water temperature during the 2011 breeding period did not differ from those in the earlier breeding periods studied or that in the relevant interval in 2012. However, in 2011, our study area was subject to two episodes of torrential rain. One such episode, was associated with Typhoon no. 1106 (1106 MA-ON), which affected our area on 20 and 21 July, and the other termed the 'Nigata Fukushima downpour', occurred between 26 and 30 July. During these rain episodes, the water temperature in the pond temporarily dropped dramatically, by over $10{ }^{\circ} \mathrm{C}$ (Fig. 5).

\section{DISCUSSION}

Three taxa of arthropods declined significantly in numbers in Fukushima Prefecture after the nuclear accident [3]. Also, the pale grass blue butterfly Zizeeria maha (Kollar, 1848) suffered physiological and genetic damage [4]. However, the impact of the accident on vertebrates remains under investigation. 


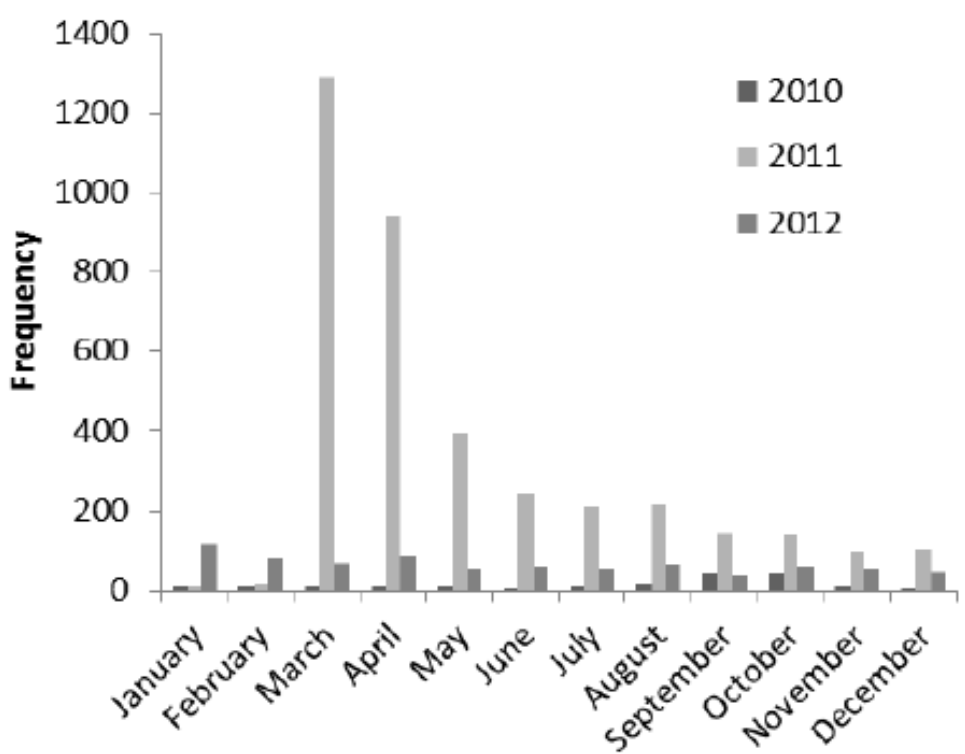

Fig. (4). Frequencies of earthquakes of seismic intensity 1.0 or more from January 2010 to October 2012. Durations of breeding periods are shown by black (2011) and white (2010) bars terminated by arrowheads.

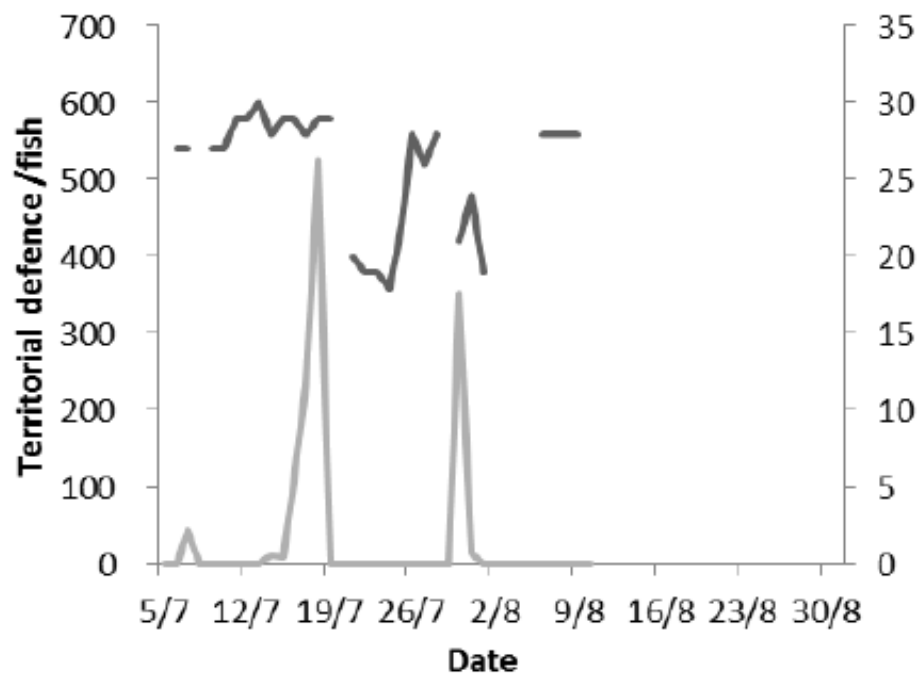

Fig. (5). Changes in the water temperature of our study pond, and episodes of territorial defence activity by male bluegills, in 2011. Breaks in the lines indicate that data were unobtainable because of adverse weather. Arrows indicate the times of group spawnings and of the occurrence of torrential rains. WT: water temperature.

Several earlier surveys of areas contaminated by radiation have found that teleost fish and other vertebrates were negatively affected $[5,6]$. For example, higher-than-normal levels of DNA strand breaks were noted in female mosquitofish Gambusia affinis (Baird \& Girard, 1853) collected from the Oak Ridge Reservation of the US Department of Energy; an air dose rate of 43.8 rads/year was measured at the surface of sediment in this area [7]. Catfish Ictalurus punctatus (Rafinesque, 1818) from the cooling pond of the Chernobyl nuclear power plant exhibited a greater number of DNA stand breaks than do control fish [8]. Such genetic damage remained evident 20 years after Chernobyl [9]. Furthermore, a 'dose rate - effect' scale has been developed to measure radiation-induced damage in fish living in northern temperate waters. A dose of $1 \mathrm{mGy} / \mathrm{day}$ causes the first observable negative changes: the immune system is affected. A dose of 5 to $10 \mathrm{mGy} /$ day negatively affects reproduction, and a dose over $10 \mathrm{mGy} / \mathrm{day}$ reduces lifespan in adult fish $[10,11]$. However, these effects are chronic in nature, and the dose rates in question are much higher than those resulting from the Fukushima accident. The acute effects of low radiation dose rates on animal behaviour remain to be investigated.

The wind was from the south in Iwaki at the time of the nuclear accident, and radioactive materials were transported principally to the northern regions of Fukushima Prefecture-particularly the districts of Iitate and Naka-Dori. Then, the level of contamination in our study area was lower than in other areas of Fukushima (Fig. 1 and Fig. 3). Although we did not monitor radioactivity levels in fish during the 2011 breeding period, we suggest that our study fish were exposed to only relatively low levels of radiation. Furthermore, radiation from pond mud would have been absorbed by the pond water. In addition, territorial males be- 
Table 2. Individual facts after the earthquake, and the supporting or mitigating hypothesis to the fact about the reproductive behavior of bluegill in 2011.

\begin{tabular}{|c|c|c|c|}
\hline Date & Individual Fact & Supporting Hypothesis & Mitigating Hypothesis \\
\hline March, 11, 2011 & A magnitude 9.0 earthquake striked. & - & - \\
\hline March, 12 & $\begin{array}{l}\text { A hydrogen explosion occured at the Unit } 1 \text { reactor building } \\
\text { of Fukushima Daiichi NPP. }\end{array}$ & - & - \\
\hline March, 13 & $\begin{array}{c}\text { A hydrogen explosion occured at the Unit } 3 \text { reactor building } \\
\text { of Fukushima Daiichi NPP. }\end{array}$ & - & - \\
\hline March, 14 & $\begin{array}{l}\text { An explosion sound is heard at Unit2. A wall was damaged } \\
\text { by a explosion at Unit } 4 \text { and a fire started. }\end{array}$ & - & - \\
\hline March, 15 & A fire at unit 4 extinguished. & - & - \\
\hline April, 11 & A serious aftershock striked at the area. & - & - \\
\hline June, 20 & Newly build but abandoned nine nests of bluegill were found. & $\begin{array}{l}\text { Onset of breeding season was delayed } \\
\text { by the frequent aftershocks. }\end{array}$ & $\begin{array}{l}\text { Reproductive sequence was sur- } \\
\text { pressed by radiation. }\end{array}$ \\
\hline July, 6 & $\begin{array}{l}\text { Newly build nests were found again and the males began to } \\
\text { protect the nests. }\end{array}$ & - & - \\
\hline July, 18 & Spawning behavior was comfirmed. & - & - \\
\hline July, 20-21 & A typhoon hit the area. & \multirow{2}{*}{$\begin{array}{l}\text { Rapid fall in water temperature dis- } \\
\text { turbed the reproductive behavior. }\end{array}$} & \multirow{2}{*}{$\begin{array}{l}\text { Gonadal damage by radiation re- } \\
\text { duced the frequency of spawning. }\end{array}$} \\
\hline July, 26-30 & 'Nigata Fukushima downpour', occurred. & & \\
\hline July, 30 & Spawning behavior was comfirmed. & - & - \\
\hline August, 1 & All nests were abandoned & - & - \\
\hline January, 16, 2012 & $\begin{array}{l}\text { Some fish was captured and measured their length and body } \\
\text { and gonad weights. The radioactive concentrations of fish } \\
\text { were also measured. }\end{array}$ & $\begin{array}{l}\text { Detected radioactivity was low not at } \\
\text { the causative level of DNA damages. }\end{array}$ & $\begin{array}{l}\text { Transient exposure to high-dose } \\
\text { radiation caused negative effect to } \\
\text { the reproductive behavior. }\end{array}$ \\
\hline
\end{tabular}

haved more aggressively in 2011 than in previous years, suggesting that the fish were not weakened by radiation. In summary, we suggest that radiation caused neither the observed delay, in 2011, of the start of bluegill spawning, nor the reduction in spawning frequency observed in that year.

The delay in breeding onset may have been caused by the high numbers of aftershocks. Breeding started at a time when the frequency of aftershocks had dropped to a plateau (Fig. 4). Several reports on the effects of earthquakes on fish behaviour have appeared. For example, demersal cichlid fishes in Lake Marawi in 1989 [12], and red snapper Lutjanus campechanus (Poey, 1860) in Alaskan waters in 1964 [13], exhibited prolongation of lateral movement behaviour after earthquakes. In our study area, the 11 April aftershock of seismic intensity 6.0 increased the frequencies of further aftershocks and brontides. Noise and vibration may be serious stressors of fish [14, 15]. Furthermore, the two episodes of torrential rain that occurred in July 2011 may have disturbed spawning. Because of these rains, the water temperature of the pond fell, temporarily, by over $10{ }^{\circ} \mathrm{C}$, although the average water temperature throughout the breeding sea- son was not affected (Table 1). In line with this suggestion, we observed only three group spawnings in 2008, when our area experienced a chilly summer (Table $\mathbf{1}$ ).

We conclude that the post-earthquake irregularities in the behavioural patterns of bluegill in our study pond were caused by factors other than radioactive contamination. The delay in breeding onset may have been caused by the occurrence of frequent aftershocks, and the reduced number of group spawning events may have been due to the unusually severe rainfall events of July. In other words, there is no evidence that the observed behavioural changes were caused by damage to DNA. Any potential chronic impact of radiation on fish behaviour requires further evaluation. Individual facts and hypothesis to the fact about the reproductive behavior of bluegill is listed on Table 2 .

It is too simplistic to attribute all ecosystem damage in Fukushima Prefecture to the accident at the Fukushima Daiichi NPP. Unlike the case with Chernobyl, the disaster at Fukushima was not a single event, but rather a series of misfortunes. These were a violent principal earthquake, frequent 
aftershocks, tsunami damage, land contamination by ocean salt, chemical contamination from rubble, and radioactive contamination. The consequences of these effects were many. Not all of the harm was caused by radioactivity.

\section{CONFLICT OF INTEREST}

The authors confirm that this article content has no conflicts of interest.

\section{ACKNOWLEDGEMENTS}

We would like to thank Iwaki Public Office of Fukushima Pref. Gov. and Agricultural Land Division of Iwaki City for the permission for the usage of the water reservoir.

\section{REFERENCES}

[1] Ministry of the Environment, Government of Japan, Ed. Impact on blackbass and bluegill upon the populations of native species: effects of blackbass and bluegill upon the populations of native species and ecosystems, and their countermeasures. Japan Wildlife Research Center, Tokyo, Japan. 2004; pp. 33-59 (In Japanese).

[2] Gross MR, Charnov EL. Alternative male life histories in bluegill sunfish. Proc Natl Acad Sci 1980; 77: 6937-40.

[3] Møller AP, Nishiumi I, Suzuki H, Ueda K, Mousseaue TA. Differences in effects of radiation on abundance of animals in Fukushima and Chernobyl. Ecol Indicators 2013; 24: 75-81.

[4] Hiyama A, Nohara C, Kinjo S, et al. The biological impacts of the Fukushima nuclear accident on the pale grass blue butterfly. Sci Rep 2012; 2: 570. doi: 10.1038/srep00570.
[5] Møller AP, Mousseau TA, Milinevsky G, Peklo A, Pysanets E, Szép T. Condition, reproduction and survival of barn swallows from Chernobyl. J Anim Ecol 2005; 74: 1102-11.

[6] Møller AP, Bonisoli-Alquati A, Rudolfsen G, Mousseau TA. Chernobyl birds have smaller brains. PLoS One 2011; 6: e16862.

[7] Theodorakis CW, Blaylock BG, Shugart LR. Genetic ecotoxicology I: DNA integrity and reproduction in mosquitofish exposed in situ to radionuclides. Ecotoxicology 1997; 6: 205-18.

[8] Sugg DW, Bickham JW, Brooks JA, et al. DNA damage and radiocesium in channel catfish from Chernobyl. Environ Toxicol Chem 1996; 15: 1057-63.

[9] Belova NV, Emel'yanova NG. Status of the reproductive system of bony fish from the Teterev River and the Kiev Reservoir 20 years after the Chernobyl accident. J Ichthyol 2009; 49: 793-802.

[10] Sazykina TG, Kryshev AI. (2003) EPIC database on the effects of chronic radiation in fish: Russian/FSU data. J Environ Radioact 2003; 68: 65-87.

[11] Kryshev AI, Sazykina TG, Sanina KD. Modelling of effects due to chronic exposure of a fish population to ionizing radiation. Radiat Environ Biophys 2008; 47: 121-9.

[12] Tweddle D, Crossley R. Effects of an earthquake on demersal cichlid fishes of southern Lake Malawi. J Fish Biol 1991; 38: 3058.

[13] Kachadoorian R. Effects of the Earthquake of March 27, 1964 At Whittier, Alaska, United States Government Printing Office, Washington, USA. 1966; pp. 5-9.

[14] Rose A, Thomas J, LaPointe A. Effects of varying noise and vibration on behavioural and physiological stress responses in two species of freshwater aquarium fish: Fathead minnow (Pimephales promelas) and bluegill sunfish (Lepomis macrochirus). J Acoust Soc Am 2008; 124: 2435.

[15] Wysocki LE, Dittami JP, Ladich F. Ship noise and cortisol secretion in European freshwater fishes. Biol Conserv 2006; 128: 501-8.

Received: November 15, 2013

(C) Iwata et al.: Licensee Bentham Open.

This is an open access article licensed under the terms of the Creative Commons Attribution Non-Commercial License (http://creativecommons.org/licenses/ by-nc/3.0/) which permits unrestricted, non-commercial use, distribution and reproduction in any medium, provided the work is properly cited. 